\title{
Bacillus megaterium 501 rif КАК АНТИДОТ ГЕРБИЦИДА ПРОМЕТРИНА В ПОСЕВАХ ОВСА И КУКУРУЗЫ
}

\author{
Ю.В. КРУГЛОВ, Т.О. ЛИСИНА, Е.Е. АНДРОНОВ
}

Использование гербицида прометрина - 4,6-бис-(изопропиламино)-2-метилтио-1,3,5триазина для борьбы с сорняками на посевах сельскохозяйственных культур приводит к возникновению ряда агротехнологических и экологических проблем в связи с его относительно высокой персистентностью в окружающей среде. Предпринимаются попытки использовать для биоремедиации почв микроорганизмы. Особый интерес представляют споровые бактерии Bacillus megaterium, продуцирующие ряд физиологически активных веществ, повышающие эффективность фотосинтеза, стимулирующие рост и формирование генеративных органов растений, а также утилизирующие некоторые пестициды. В настоящей работе впервые показано, что культура $B$. megaterium $501^{\text {rif }}$ снижает фитотоксичность гербицида и разлагает его в ризосфере овса и кукурузы. Целью работы было изучение приживаемости культуры Bacillus megaterium $501^{\text {rif }}$ в ризосфере овса и кукурузы, оценка ее влияния на устойчивость растений к прометрину и эффективность разложения этого гербицида в почве. B. megaterium 501 rif - мутант, устойчивый к антибиотику рифампицину, получен методом градиентного отбора из исходного штамма, выделенного нами из чернозема обыкновенного (Кокчетавская обл., Казахстан). Для проведения вегетационных опытов B. megaterium $501^{\text {rif }}$ выращивали на ротационной качалке в течение 48 ч при $30{ }^{\circ} \mathrm{C}$ и 140 об/мин. Титр бактерий составлял $5 \times 10^{8} \mathrm{KOE} /$ мл и включал не менее $90 \%$ вегетативных клеток. Семена овса посевного (Avena sativa L.) сорта Победа и кукурузы (Zeal mays L.) сорта Росс 199 Мв инокулировали 2суточной жидкой культурой $B$. megaterium $501^{\text {rif }}$, после чего высаживали в вегетационные сосуды объемом 2,0 кг. Почва - дерново-подзолистая, среднесуглинистая, с содержанием органического вещества $2,3 \%$, рНсол. 5,8 . Гербицид прометрин в виде водной суспензии смачивающегося порошка («Panama Agrochemical Inc.», Панама) вносили в количестве 0,12; 0,22; 0,67 и 1,23 мг/кг в опыте с овсом и 3,4; 6,8 и 20,4 мг/кг в опыте с кукурузой. В последнем случае дополнительно был введен вариант с парующей почвой, содержащей прометрин $(6,8$ мг/кг). Контролем служили аналогичные варианты без инокуляции. Растения выращивали в световой камере Фитос-4 (ФГУП «Фитос», Россия) при температуре $22-25^{\circ} \mathrm{C}$. Сухую биомассу растений, содержание прометрина в почве и численность бактерий в ризосфере учитывали через 30 сут после появления всходов. Полевой опыт проводили в 2010 году на опытном поле Всероссийского НИИ сельскохозяйственной микробиологии (г. Пушкин, Ленинградская обл.). Почва - дерново-подзолистая среднесуглинистая, с содержанием органического углерода $2,3 \%$, pH 5,6. Гербицид прометрин вносился в верхний слой почвы на глубину 0-10 см в дозе 500 мг/м², что соответствует 1,5 мг/кг. Семена кукурузы сорта Росс 199 Мв перед посевом инокулировали жидкой культурой $B$. megaterium $501^{\text {rif }}$ с титром $5 \times 10^{8} \mathrm{KOE} /$ мл. В контрольном варианте инокуляцию не проводили. Наземную массу растений и содержание гербицида в почве определяли спустя 30 сут после появления всходов. Бацилла $\boldsymbol{B}$. megaterium $501^{\text {rif }}$ хорошо приживалась в ризосфере овса и кукурузы. Численность бактерий составляла от 300 до 500 тыс. КОЕ/г почвы, причем от 58 до $80 \%$ бактерий находилось в виде физиологически активных вегетативных клеток. При инокуляции культурой $B$. megaterium $501^{\text {rif }}$ биомасса овса в варианте без гербицида возрастала на $11 \%$, кукурузы - на $20 \%$. Эффективность инокуляции увеличивалась на фоне прометрина. Существенно повышалась устойчивость растений к гербициду, содержание прометрина в почве под овсом снижалось в 2-3 раза, под кукурузой - в 20 раз. В полевых опытах через 30 сут после появления всходов масса растений кукурузы в контроле составляла

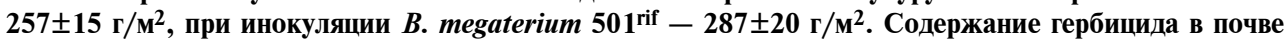
в варианте с инокуляцией уменышалось почти в 3 раза по сравнению с контролем $(0,15 \pm 0,03$ против $0,45 \pm 0,10$ мг/кг). Предполагается, что механизм протекторного действия бактерий $B$. megaterium $501^{\text {rif }}$ по отношению к гербициду обусловлен, с одной стороны, положительным влиянием продуктов их жизнедеятельности, в частности поли-бета-гидроксимасляной кислоты, на растения, с другой - активным участием микроорганизмов в деградации прометрина. Таким образом, $B$. megaterium 501 rif, подобно антидоту, снимает фитотоксическое действие гербицида на растения и повышает их продуктивность. Кукуруза, инокулированная бактериями, эффективно очищает почву от прометрина и может использоваться в качестве биомелиоранта.

Ключевые слова: Bacillus megaterium, протектор, антидот, прометрин, деградация гербицида, овес, кукуруза, биоремедиация почвы.

$$
\text { Гербицид прометрин - 4,6-бис-(изопропиламино)-2-метилтио-1,3,5- }
$$

\footnotetext{
* Работа выполнена при поддержке РНФ (проект № 18-16-00073).
} 
триазин широко и эффективно применяется для борьбы с однолетними двудольными и злаковыми сорняками в посевах кукурузы, хлопчатника, сои, картофеля, а также овощных и зеленных культур $(1,2)$. Его персистентность (Т50) в почве в зависимости от дозы, почвенно-климатических условий и агротехнических приемов использования составляет от нескольких недель до 18 мес $(3,4)$. Длительное присутствие гербицида в почве обусловливает ряд проблем агротехнологического и экологического характера. С агрономической точки зрения они связаны прежде всего с чередованием сельскохозяйственных культур в севообороте. Имеется значительный риск снижения урожая и даже гибели чувствительных к гербициду растений, высеянных по предшественнику, обработанному прометрином. С экотоксикологической точки зрения следует отметить, что, несмотря на относительно низкую подвижность, прометрин и продукты его трансформации вымываются из почвы в окружающие водоемы, оказывая отрицательное влияние на водную растительность и подрывая кормовую базу гидробионтов $(5,6)$.

Основные факторы разложения гербицидов - физико-химические свойства почвы и микроорганизмы $(6,7)$. Из почвы выделены бактерии, использующие прометрин в качестве источника углерода $(8)$, азота $(9,10)$ и серы (11). По данным Ю.В. Круглова с соавт. (12), в почве, инокулированной культурой Bacillus megaterium 501 rif, наблюдалось ускоренное разложение гербицида. Некоторые штаммы B. megaterium продуцируют поли-бетагидрокимасляную кислоту. Установлено, что обработка посевов препаратом, содержащим это вещество, повышает устойчивость растений к стрессам, включая некоторые пестициды (13). На основе B. megaterium созданы препараты, которые используются в растениеводстве для повышения урожая сельскохозяйственных культур $(14,15)$. Вместе с тем практически отсутствуют работы, в которых изучено влияние этих микроорганизмов на устойчивость растений к гербицидам, широко и повсеместно используемым в современных агротехнологиях.

В настоящем исследовании получены новые данные о последствиях инокуляции B. megaterium 501 rif для растений в отношении их устойчивости к гербициду прометрину. Впервые показано, что культура B. megaterium $501^{\text {rif }}$ снижает фитотоксичность гербицида и разлагает его в ризосфере овса и кукурузы.

Целью работы было изучение приживаемости культуры Bacillus megaterium 501 rif в ризосфере овса и кукурузы, оценка ее влияния на устойчивость растений к прометрину и эффективность разложения этого гербицида в почве.

Методика. Вегетационные опыты проводили на экспериментальной базе ФГБНУ Всероссийского НИИ сельскохозяйственной микробиологии (г. Пушкин).

B. megaterium 501rif (мутант, устойчивый к антибиотику рифампицину) был получен методом градиентного отбора из исходного штамма, выделенного нами из чернозема обыкновенного (Кокчетавская обл., Казахстан). Исходный штамм депонирован в Коллекции непатогенных полезных микроорганизмов сельскохозяйственного назначения (ФГБНУ Всероссийский НИИ сельскохозяйственной микробиологии) (16).

B. megaterium 501 rif выращивали на ротационной качалке в течение 48 ч при $30^{\circ} \mathrm{C}$ и 140 об/мин. Состав питательной среды был следующим (г/л): $\mathrm{K}_{2} \mathrm{HPO}_{4}-1,6 ; \mathrm{KH}_{2} \mathrm{PO}_{4}-0,4 ; \mathrm{NH}_{4} \mathrm{NO}_{3}-0,5 ; \mathrm{MgSO}_{4}-0,2 ;$ $\mathrm{CaCO}_{3}-0,05 ; \mathrm{FeSO}_{4}-0,025 ;$ дрожжевой экстракт - 0,2; сахароза - 10,0; pH 6,8. Титр бактерий составлял $5 \times 10^{8} \mathrm{KOE} /$ мл (не менее $90 \%$ вегетативных клеток). 
Накопление поли-бета-гидроксимасляной кислоты (в виде гранул) в клетках B. megaterium 501 rif исследовали методом фазово-контрастной микрскопии (Axio Lab. A1, «Carl Zeiss», Германия).

Семена овса посевного (Avena sativa L.) сорта Победа и кукурузы (Zeal mays L.) сорта Росс 199 Мв инокулировали 2-суточной жидкой культурой $B$. megaterium $501^{\text {rif }}$, после чего высаживали в вегетационные сосуды объемом 2,0 кг. Почва - дерново-подзолистая среднесуглинистая, с содер-

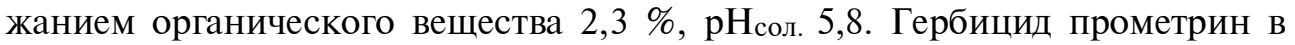
виде водной суспензии смачивающегося порошка («Panama Agrochemical Inc.», Панама) вносили в количестве 0,0 (без гербицида), 0,12;0,22; 0,67 и 1,23 мг/кг в опыте с овсом и 0,0 (без гербицида), 3,4; 6,8 и 20,4 мг/кг - с кукурузой. В последнем случае дополнительно был введен вариант с парующей почвой, содержащей прометрин (6,8 мг/кг). Почву тщательно перемешивали и расфасовывали. Контролем служили аналогичные варианты без инокуляции.

Растения выращивали в световой камере Фитос-4 (ФГУП «Фитос», Россия) при температуре 22-25 ${ }^{\circ} \mathrm{C}$. Влажность почвы составляла 50-60 \% от полной влагоемкости. Повторность опыта 3-кратная.

Сухую биомассу растений, содержание прометрина в почве и численность $B$. megaterium $501^{\text {rif }}$ в ризосфере овса и кукурузы учитывали спустя 30 сут после появления всходов. Количество бактерий определяли методом серийных разведений (17) на агаризованной минеральной среде указанного выше состава с добавлением 2,5 \% агара («Difco», CША) и 0,02 г/л антибиотика рифампицина. Для дифференцированного определения спор бактерий почвенную суспензию перед посевом на питательную среду пастеризовали 10 мин при $80{ }^{\circ} \mathrm{C}$. Гербицид экстрагировали из почвы ацетоном с последующим количественным определением на газовом хроматографе Цвет-106 (НПО «Химавтоматика», Россия) с термоионным детектором (18). Степень экстракции прометрина из почвы составляла 65-70 \% от расчетного количества.

Полевой опыт проводили в 2010 году (опытное поле Всероссийского НИИ сельскохозяйственной микробиологии, г. Пушкин, Ленинградская

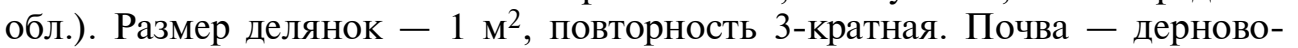
подзолистая среднесуглинистая, с содержанием органического углерода $2,3 \%, \mathrm{pH} 5,6$. Гербицид прометрин вносили в верхний слой почвы на глу-

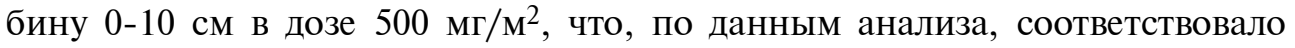
1,5 мг/кг. Семена кукурузы сорта Росс 199 Мв перед посевом инокулировали жидкой культурой B. megaterium 501 rif с титром $5 \times 10^{8} \mathrm{KOE/мЛ.} \mathrm{В} \mathrm{кон-}$ трольном варианте инокуляцию не проводили. Наземную массу растений, содержание гербицида в почве и титр бактерий определяли спустя 30 сут после появления всходов.

Статистическую обработку данных проводили в программе Microsoft Excel. Рассчитывали средние значения показателей $(M)$ и среднеквадратические отклонения $( \pm \mathrm{SD})$. Достоверность результатов оценивали на уровне доверительной вероятности Р0,95.

Результаты. В вегетационном опыте гербицид прометрин в количестве 0,12 мг/кг оказывал незначительное стимулирующее действие на рост овса. Биомасса растений по сравнению с вариантом без гербицида возрастала на $11 \%\left(\mathrm{P}_{0,05}\right)$ (рис. 1). Дозы прометрина выше 0,22 мг/кг ингибировали рост растений, а при 1,23 мг/кг уже через 2 нед происходила их гибель.

Инокуляция семян овса культурой B. megaterium 501 rif приводила к снижению фитотоксического эффекта прометрина и достоверному $\left(\mathrm{P}_{0,95)}\right.$ 
увеличению наземной массы растений по сравнению с контролем (без инокуляции) независимо от содержания гербицида в почве. Культура $B$. megaterium 501 ${ }^{\text {rif }}$ хорошо приживалась в ризосфере овса, причем от 58 до $80 \%$ бактерий находилось в виде физиологически активных вегетативных клеток. Спустя 1 мес после появления всходов содержание прометрина в почве снижалось, при этом в опытном варианте, где семена инокулировали культурой бактерий, его было в 1,5-3,0 раза меньше, чем в контроле (табл.). Следовательно, B. megaterium 501 rif оказывала протекторное действие на pacтения овса, повышая их устойчивость к гербициду, а также снижала содержание гербицида в почве, что, в свою очередь, уменьшало его фитотоксический эффект.

Аналогичное действие прометрин оказывал на кукурузу, однако ее устойчивость была на порядок выше, чем у овса (см. рис. 1). Ингибирующий эффект гербицида проявлялся при концентрации 20,4 мг/кг. Меньшие концентрации стимулировали рост растений. Инокуляция бактериями семян кукурузы полностью снимала фитотоксический эффект гербицида. При этом биомасса растений по сравнению с неинокулированными вариантами опыта возрастала в 1,5-3,0 раза $\left(\mathrm{P}_{0,95)}\right.$.

Бактерии B. megaterium 501 rif прекрасно приживались в ризосфере растений, достигая численности 335 тыс. КОЕ г/почвы (см. табл.). Через 30 сут после всходов содержание гербицида в почве под кукурузой снижалось в 20 раз, а при инокуляции бактериями - в 60 раз по сравнению с парующей почвой. Следовательно, в деградации гербицида участвовали как растения, так и бактерии B. megaterium 501 rif, присутствующие в ризосфере.
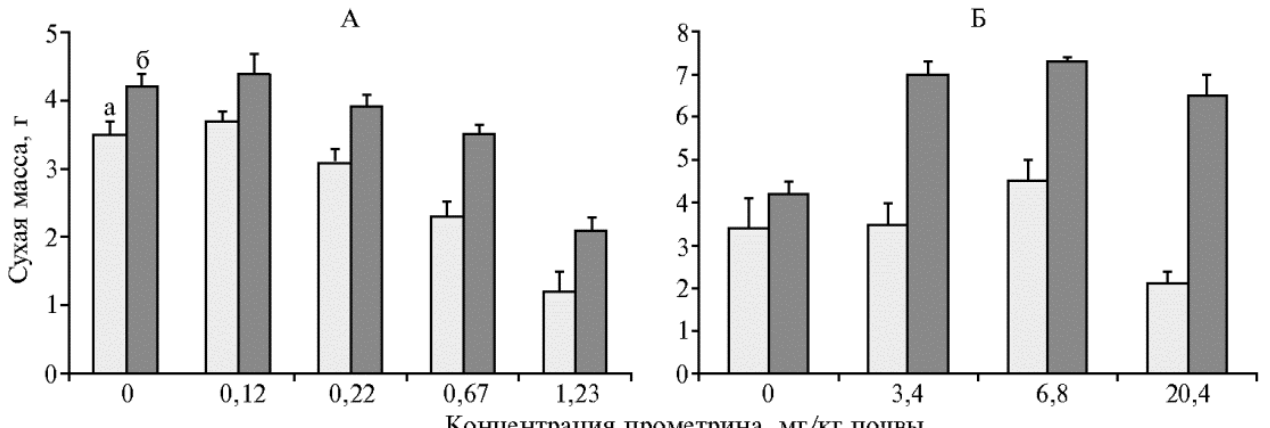

Рис. 1. Сухая масса растений овса посевного (Avena sativa L.) сорта Победа (А) и кукурузы (Zeal mays L.) сорта Росс 199 Мв (Б) под влиянием гербицида прометрина при инокуляции семян культурой Bacillus megaterium 501 rif (30-е сут после появления всходов): а - контроль (без инокуляции), б - опыт (вегетационный опыт, вертикальные отрезки - среднеквадратические отклонения).

Содержание прометрина и бактериального инокулянта Bacillus megaterium 501 rif в почве под овсом посевным (Avena sativa L.) сорта Победа и кукурузой (Zeal mays L.) сорта Росс 199 Мв (30-е сут после появления всходов) (вегетационный опыт, $M \pm \mathrm{SD}$ )

\begin{tabular}{|c|c|c|c|c|c|}
\hline \multirow{3}{*}{ Почва } & \multicolumn{3}{|c|}{ Прометрин, мг/кг } & \multirow{2}{*}{\multicolumn{2}{|c|}{ B. megaterium $501^{\text {rif }}$, KOE тыс/г }} \\
\hline & \multirow[b]{2}{*}{ исходное } & \multicolumn{2}{|c|}{ 30-е сут } & & \\
\hline & & $\begin{array}{l}\text { без инокуля- } \\
\text { ции }\end{array}$ & $\begin{array}{l}\text { инокуляция семян } \\
\text { B. megaterium } 501^{\text {rif }}\end{array}$ & общее число & $\begin{array}{l}\text { споры, \% от } \\
\text { общего числа }\end{array}$ \\
\hline Под овсом & $0,22 \pm 0,03$ & $<0,02$ & $<0,02$ & $500 \pm 70$ & 20,0 \\
\hline Под овсом & $0,67 \pm 0,04$ & $0,59 \pm 0,02$ & $0,18 \pm 0,03$ & $550 \pm 65$ & 27,0 \\
\hline Под овсом & $1,23 \pm 0,03$ & $0,93 \pm 0,15$ & $0,58 \pm 0,07$ & $350 \pm 33$ & 42,0 \\
\hline Под кукурузой & $6,80 \pm 0,05$ & $0,22 \pm 0,02$ & $0,07 \pm 0,02$ & $335 \pm 40$ & 12,0 \\
\hline Почва (без кукурузы) & $6,80 \pm 0,05$ & $4,50 \pm 0,07$ & & & \\
\hline
\end{tabular}

Учитывая высокую эффективность деградации гербицида под по- 
кровом кукурузы, провели оценку влияния бактерий на накопление зеленой массы растений и деградацию прометрина в почве в условиях микроделяночного полевого опыта. Через 30 сут после появления всходов масса растений в контроле составляла $257 \pm 15$ г/м ${ }^{2}$, в то время как при инокуляции

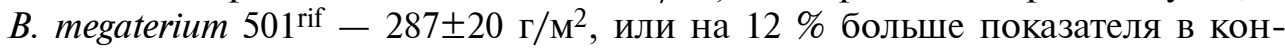
троле. Разница между вариантами опыта практически отсутствовала. Содержание гербицида в почве в варианте с инокуляцией уменьшалось почти в 3 раза по сравнению с контролем - 0,15 $\pm 0,03$ против $0,45 \pm 0,10$ мг/кг, что согласуется с результатами вегетационного опыта.

Рассматривая причины положительного эффекта B. megaterium 501 rif, следует обратить внимание на то, что у инокулированных бактериями растений существенно изменяется архитектура корневой системы за счет более интенсивного развития боковых корней (19), ускоряется формирование генеративных органов (20), возрастает суммарное содержание фотосинтетических пигментов в листьях (21).

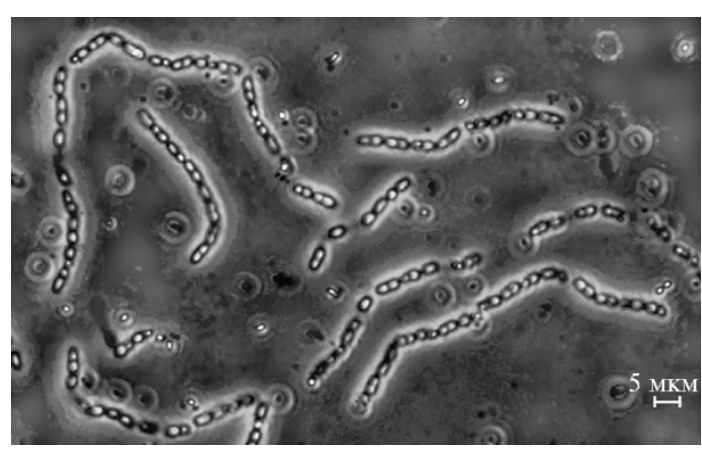

Рис. 2. Клетки Bacillus megaterium 501 rif, наполненные гранулами поли-бета-гидроксимасляной кислоты (микроскоп Axio Lab. A1, «Carl Zeiss», Германия, фазовый контраст).

Среди продуктов жизнедеятельности этих микроорганизмов обнаружены ауксины и витамины группы В (22), а также полибета-гидроксимасляная кислота (23-26), которые оказывали положительное влияние на формирование корневой системы растений и фотосинтез. Содержание поли-бета-гидроксимасяной кислоты в клетках B. megaterium coставляло от 10 до $80 \%$ от массы бактерий в зависимости от штамма и условий культивирования (2325). Полученный нами штамм B. megaterium 501 rif при росте на жидкой среде также интенсивно синтезировал и накапливал в вегетативных клетках гранулы поли-бета-гидроксимасляной кислоты (рис. 2).

Результаты испытаний препарата Альбит (ООО «Научно-производственная фирма «Альбит», Россия), основным действующим веществом которого служит поли-бета-гидроксимасляная кислота, показали высокую эффективность его применения в посевах ряда сельскохозяйственных культур на фоне различных по химическому составу гербицидов $(13,27)$. А.К. Злотников с соавт. $(13,27)$ рассматривают Альбит как универсальный антистрессовый препарат, обладающий свойствами антидота по отношению к применяемым в сельском хозяйстве ядохимикатам. По мнению авторов, механизм его протекторного действия на растение связан прежде всего с положительным влиянием поли-бета-гидроксибутирата на фотосинтез. Исходя из этого, можно полагать, что протекторное действие B. megaterium $501^{\text {rif }}$ на растения в наших опытах с высокой долей вероятности было связано с положительным эффектом продуктов жизнедеятельности бактерий, прежде всего поли-бета-гидроксимасляной кислоты.

Особый интерес представляют результаты опытов с кукурузой. Известно, что кукуруза поглощает и разлагает триазиновые гербициды. При этом значительную роль играют ферменты, участвующие в реакции гидроксилирования (28). Установлено, что при трансформации прометрина растением и микроорганизмами образуется значительное количество продуктов метаболизма, среди которых основное место занимают сульфоксид, сульфон, 
гидроксипропазин, а при последующей трансформации гидроксипропазина возможно образование амелина, амелида и циануровой кислоты. Продукты гидролиза и $\mathrm{N}$-деалкилирования сим-триазинов образуют конъюгаты с глютатионом и сахарами $(6,28)$.

До сих пор основное внимание исследователей было сосредоточено на изучении гербицидного эффекта прометрина и продуктов его трансформации (29). Имеется очень мало данных об их положительном действии на растения. Так, в опытах Е.В. Лебедева $(30,31)$ малые дозы прометрина повышали чистую продуктивность фотосинтеза, поглощение азота и фосфора сеянцами сосны обыкновенной и кедра сибирского. В работе H.M. Nadar c соавт. (32) наблюдалось стимулирующее действие сим-триазиновых гербицидов, включая метилтиопризводные (прометрин и аметрин), на рост каллуса сорго и синтез белка, на основании чего авторы пришли к выводу о гормональном кинин-подобном действии малых концентраций сим-триазинов на растение. Триазиновые гербициды оказывают влияние на ионный баланс растений и, соответственно, на синтез ДНК, белков и энзимов (33), поэтому не исключено, что высокая эффективность инокуляции кукурузы культурой $B$. megaterium $501^{\text {rif }}$ на фоне прометрина обусловлена синергическим эффектом продуктов жизнедеятельности бациллы, гербицида и продуктов его трансформации.

Таким образом, инокуляция семян овса и кукурузы культурой Bacillus megaterium 501 rif оказывала положительное влияние на рост растений. Причем эффективность инокуляции на фоне гербицида прометрина была выше, чем в контроле. Также повышалась устойчивость растений к прометрину и ускорялось его разложение в ризосфере. Следовательно, культура бактерий $B$. megaterium $501^{\text {rif }}$ и продукты ее жизнедеятельности, в частности поли-бета-гидроксимасляная кислота, служат протекторами, или антидотами, снимающими фитотоксический эффект прометрина. Показано, что кукуруза, инокулированная $B$. megaterium $501^{\text {rif }}$, в условиях вегетационного и микрополевого опытов проявила себя как биомелиорант, эффективно очищающий почву от прометрина. Это открывает перспективы для использования инокулированной бациллой кукурузы в биоремедиации загрязненной гербицидом почвы.

\section{ЛИТ РАТУРА}

1. Государственный каталог пестицидов и агрохимикатов, разрешенных к применению на территории Российской Федерации. М., 2013.

2. Новожилов К.В., Долженко В.И. Средства защиты растений. М., 2011.

3. Koskinen W.C., Banks P.A. Soil movement and persistence of triazine herbicides. In: The triazine herbicides: 50 years revolutionizing agriculture /H.M. LeBaron, J.E. McFarland, O.C. Burnside (eds.). Elsevier BV, Amsterdam, Boston, Heidelberg, London, New York, Paris, San Diego, San Francisco, Sydney, Tokio, 2008: 355-385 (doi: 10.1016/B978-044451167-6.50027-1).

4. Scott M. Herbicide residues in soil and water. SMART train chemical notes 3, 2008.

5. Risks of prometryn use to federally threatened California red-legged frog (Rana aurora draytonii). Pesticide effects determination environmental fate and effects. Division Office of Pesticide Programs Washington, D.C. 20460 6.17.2009.

6. Мельников Н.Н., Волков А.И., Короткова О.А. Пестициды и окружающая среда. М., 1977.

7. Charles S. Soil residual herbicides: science and management. In: Topics in Canadian weed science /R.C. Van Acker (ed.). Sainte-Anne-de Bellevue, Québec, Canadian Weed Science Society Société canadienne de malherbologie, 2005, 3: 3-22.

8. Игнатовец О.С., Леонтьев В.Н. Механизм деградации прометрина бактериями рода Pseudomonas. Доклады НАН Беларуси, 2008, 52(3): 82-86.

9. Myśków W., Lasota T., Stachyra A. Cyanuric acid--a s-triazine derivate as a nitrogen source for some soil microorganisms. Acta Microbiologica Polonica, 1983, 32(2): 80-85.

10. Cook A.M., Hütter R. Triazines as nitrogen sources for bacteria. J. Agric. Food Chem., 1981, 29(6): 1135-1143 (doi: 10.1021/jf00108a009).

11. Cook A.M., Hütter R. Ametryne and prometryne as sulfur sources for bacteria. Applied Environmental Microbiology, 1982, 43(4): 781-786 (doi: 10.1128/aem.43.4.781-786.1982). 


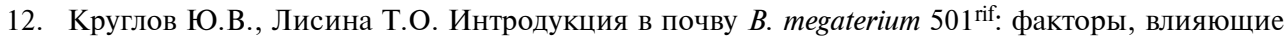
на выживание, спорообразование и разложение гербицида прометрина. Сельскохозяйственная биология, 2014, 5: 107-112 (doi: 10.15389/agrobiology.2014.5.107rus).

13. Злотников А.К. Разработка и комплексная характеристика полифункиионального препарата альбит для защиты растений от болезней и стрессов. Автореф. докт. дис. Пущино-Рамонь, 2011.

14. Доросинский Л.М. Бактериальные удобрения - дополнительное средство повышения урожая. М., 1965.

15. Chumthong A., Kanjanamaneesathian M., Pengnoo A., Wiwattanapatapee R. Water-soluble granules containing Bacillus megaterium for biological of rice sheath blight: formulation, bacterial viability efficacy testing. World J. Microbiol. Biotechnol., 2008, 24(11): 2499-2507 (doi: 10.1007/s11274-008-9774-7).

16. Гаврилова Е.А., Лисина Т.О., Круглов Ю.В. Штамм В. теgaterium, предназначенный для деструкции фосфорорганических пестицидов. А.с. 1735359 A1. (РФ). Всесоюзный научно-исследовательский институт сельскохозяйственной микробиологии (РФ). №4781535. Заявл. 11.01.90. Опубл. 23.05.92. Бюл. 19.

17. Методы почвенной микробиологии и биохимии /Под ред. Д.Г. Звягинцева. М., 1991.

18. Методы определения микроколичеств пестицидов в продуктах питания, кормах и внешней среде /Под ред. М.А. Клисенко. М., 1983.

19. López-Bucio J., Campos-Cuevas J.C., Hernández-Calderón E., Velásquez-Becerra C., FaríasRodríguez R., Macías-Rodríguez L.I., Valencia-Cantero E. Bacillus megaterium rhizobacteria promote growth and alter root-system architecture through an auxin- and ethylene-independent signaling mechanism in Arabidopsis thaliana. Molecular Plant Microbe Interaction, 2007, 20(2): $207-$ 217 (doi: 10.1094/MPMI-20-2-0207).

20. Лисина Т.О., Гаранькина Н.Г., Круглов Ю.В. Влияние интродуцируеых в почву микроорганизмов деструкторов пестицидов на рост и развитие растений. Прикладная биохимия $u$ микробиология, 2001, 37(3): 374-378.

21. Субботин А.М., Нарушко М.В., Петров С.А. Штамм микроорганизмов Bacillus megaterium 2-06-TS1 в качестве активатора фотосинтеза и энергии прорастания растений. Пат. 2627608 С1 (РФ). ФГБУН Тюменский научный центр СО РАН (РФ). № 2016125604. Заявл. 27.06.2016. Опубл. 09.08.2017, Бюл. № 22.

22. Возняковская Ю.М. Микрофлора растений и урожай. Л., 1969.

23. Otari S.V., Ghosh J.S. Production and characterization of the polymer polyhydroxy butyrate-copolyhydroxy valerate by Bacillus megaterium NCIM 2475. Current Research Journal of Biology Sciences, 2009, 1(2): 23-26.

24. Mohapatra S., Maity S., Dash H.R., Das S., Pattnaik S., Rath C.C., Samantaray D. Bacillus and biopolymer: prospects and challenges. Biochemistry and Biophysics Reports, 2017, 12: 206-213 (doi: 10.1016/j.bbrep.2017.10.001).

25. Mona K., Gouda A., Swellam A., Omar S. Production of PHB by a Bacillus megaterium strain, using sugarcane molases and corn steep liquor as sole carbon and nitrogen source. Microbiology Research, 2001, 156(3): 201-207 (doi: 10.1078/0944-5013-00104).

26. Kofroňová O., Ptáčková L., Chaloupka J. Poly(3-hydroxybutyrate) granules of Bacillus megaterium. Folia Microbiologica, 1994, 39(2): 166-167 (doi: 10.1007/BF02906816).

27. Злотников А.К., Злотников К.М., Подварко А.Т., Балахоненков В.Е., Хрюкина Е.И. Альбит как антидот при сочетании с послевсходовыми гербицидами на сое. Земледелие, 2010, 3: 40-41.

28. Simoneaux B.J., Gould T.J. Plant uptake and metabolism of triazine herbicides. In: The triazine herbicides. 50 years revolutionizing agriculture /H.M. LeBaron, J.E. McFarland, O.C. Burnside (eds.). Elsevier BV, Amsterdam, Boston, Heidelberg, London, NY, Paris, San Diego, San Francisco, Sydney, Tokio, 2008: 73-99 (doi: 10.1016/B978-044451167-6.50010-6).

29. Trebst A. The mode of action of triazine herbicides in plants. In: The Triazine herbicides. 50 years revolutionizing agriculture /H.M. LeBaron, J.E. McFarland, O.C. Burnside (eds). Elsevier BV, Amsterdam, Boston, Heidelberg, London, NY, Paris, San Diego, San Francisco, Sydney, Tokio, 2008: 101-110 (doi: 10.1016/B978-044451167-6.50011-8).

30. Лебедев Е.В. К вопросу о действии гербицида гезагарда (прометрина) на сеянцы сосны обыкновенной в условиях дерново-подзолистой почвы Нижегородского Заволжья. Известия Оренбургского аграрного университета, 2011, 4(32): 21-23.

31. Лебедев Е.В. Влияние гербицида гезагарда (прометрина) на сеянцы лиственницы сибирской в условиях серых лесных почв центральной части Нижегородской области. Известия Оренбургского аграрного университета, 2012, 1(33): 23-26.

32. Nadar H.M., Clegg M.D., Maranville J.W. Promotion of sorghum callus growth by the s-triazine. Plant Physiology, 1975, 56(6): 747-751 (doi: 10.1104/pp.56.6.747).

33. Ebert E., Dumford S.W., Van Assche C.J., Warwick D.D. Effects of triazine herbicides on the physiology of plants. In: Residue reviews. Residues of pesticides and other contaminants in the total environment (continuation of residue reviews), vol. 65 /F.A. Gunther, J.D. Gunther (eds.). Springer, New York, NY, 1976 (doi: 10.1007/978-1-4613-9413-6 1). 
196608 Россия, г. Санкт-Петербург-Пушкин, ш. Подбельского, 3,

e-mail: yuvkruglov@yandex.ru $₫$, lisina-to@yandex.ru, eeandr@gmail.com

Sel'skokhozyaistvennaya biologiya [Agricultural Biology], 2020, V. 55, № 3, pp. 481-488

\title{
Bacillus megaterium 501 ${ }^{\text {rif }}$ AS ANTIDOT OF HERBICIDE PROMETRYN IN CROPS OF OATS AND CORN
}

\author{
Yu.V. Kruglov, T.O. Lisina, E.E. Andronov
}

All-Russian Research Institute for Agricultural Microbiology, 3, sh. Podbel'skogo, St. Petersburg, 196608 Russia, e-mail yuvkruglov@yandex.ru ( $₫$ corresponding author), lisina-to@yandex.ru, eeandr@gmail.com ORCID:

Kruglov Yu.V. orcid.org/0000-0001-9259-3701

Andronov E.E. orcid.org/0000-0002-5204-262X

Lisina T.O. orcid.org/0000-0003-1268-4166

The authors declare no conflict of interests

Acknowledgements:

Supported financially from Russian Science Foundation (project No. 18-16-00073)

Received November 28, 2019

doi: $10.15389 /$ agrobiology.2020.3.481eng

\section{Abstract}

The application of the herbicide prometryn (4,6-bis-(isopropylamino)-2-methylthio-1,3,5triazine) for weed control, makes many agrotechnological and ecological problems due to relatively higher persistence in the environment. It is well known that many microorganisms are capable of decomposing the herbicide. There has been some attempt to use microorganisms for bioremediation of soils. Bacillus megaterium is of particular interest because it produces many physiologically active substances that increase the efficiency of photosynthesis, stimulates growth, and accelerates the formation of plants reproductive organs, as well as decomposes some pesticides. In this article, we present new data on the effect of $B$. megaterium 501 rif inoculation upon plant resistance to the herbicide prometryn. There was shown that the $B$. megaterium $501^{\text {rif }}$ brings down the phytotoxicity of the herbicide and decomposes it in the rhizospheres of oats and corn. The purposes of the work were to study the survival rate of $B$. megaterium $501^{\text {rif }}$ in the rhizosphere of oats and maize and to estimate its effect on plant resistance to prometryn, as well as ability to effectively decomposition of this herbicide in the soil. B. megaterium $501^{\text {rif }}$ was cultured on a rotary shaker for 48 hours at $30{ }^{\circ} \mathrm{C}, 140 \mathrm{rpm}$. The bacterial titer was $5 \times 10^{8} \mathrm{CFU} / \mathrm{ml}$ and included at least $90 \%$ of the alive cells. Seeds of oats (Avena sativa $\mathrm{L}$.) cultivar Pobeda and maize (Zeal mays L.) cultivar Ross 199 MV were inoculated with a 2-days liquid culture of $B$. megaterium $501^{\text {rif }}$ and were sown in vegetative pots. The soil was soddy-podzolic, medium loam, with an organic matter content of $2.3 \%, \mathrm{pH} 5.8$. An aqueous suspension of wetting powder of prometryn (Panama Agrochemical Inc., Panama) was applied in the quantity of 0.12, 0.22, 0.67, and $1.23 \mathrm{mg} / \mathrm{kg}$ in the experiment with oats and $3.4,6.8$ and $20.4 \mathrm{mg} / \mathrm{kg}$ in the experiment with corn. In last case there was a variant with prometryn $(6.5 \mathrm{mg} / \mathrm{kg})$ but without plants. Plants were grown in the light chamber Phytos-4 (PHYTOS, Russia) at a temperature of $22-25{ }^{\circ} \mathrm{C}$. The dry weight of plants, the quantity of prometryn in the soil, and the number of bacteria in the rhizosphere were determined 30 days after the sprouts appeared. The field experiment was conducted in the experimental field of the All Russia Institute for Agricultural Microbiology (Pushkin, Leningrad region). The soil was soddypodzolic medium loam, with an organic carbon content of $2.3 \%, \mathrm{pH} 5.6$. The herbicide prometryn was applied to the soil at a dose of $500 \mathrm{mg} / \mathrm{m}^{2}$, which approximately corresponded to $1,5 \mathrm{mg} / \mathrm{kg}$. The seeds of corn were not inoculated in the control. The dry weight of plants and the quantity of herbicide in the soil were determined 30 days after the sprouts appeared. B. megaterium $501^{\text {rif }}$ took root well in the rhizospheres of oats and corn. The number of bacteria were 300 to 500 thousand CFU/g soil, and from 58 to $80 \%$ of them were physiologically active cells. The weight of oats increased by $11 \%$, corn - by $20 \%$, when seeds were inoculated with B. megaterium $501^{\text {rif }}$ culture. The resistance of plants to herbicide significantly increased and quantity of prometryn decreased 2-3-fold in the soil under oats, and 20-fold under corn. In the field experiment the weight of the corn plant was $11.6 \%$ higher, while the herbicide quantity in the soil was 3 times lower than in the control. We suppose that the higher resistance of plants inoculated with bacteria to the herbicide is due to a positive effect of their metabolites, in particular poly-beta-hidroxibutyrate, produced by bacteria as well as active participation of bacteria in the degradation of the herbicide. Thus, B. megaterium $501^{\text {rif }}$ like an antidote takes off the phytotoxic effect of the herbicide on plants and increases their productivity. Corn, when inoculated with bacteria, decomposes prometryn effectively and can be used for bioremediation.

Keywords: Bacillus megaterium, protector, antidote, prometryn, herbicide degradation, oats, corn, soil bioremediation. 